\title{
The Model of Strategies Employed by English Teachers in Teaching Writing Skill in National Plus Schools
}

\author{
Astrini, N. W. F ${ }^{1}$, Ratminingsih, N.M ${ }^{2}$, Utami, I. G.A. L.P3
}

1,23 Universitas Pendidikan Ganesha

\begin{tabular}{|c|c|}
\hline A R T I C LEINFO & A B S T R A C T \\
\hline $\begin{array}{l}\text { Article history: } \\
\text { Received } 29 \text { December } \\
2019 \\
\text { Received in revised } \\
\text { Form } 01 \text { January } 2020 \\
\text { Accepted } 18 \text { January } \\
2020 \\
\text { Available online } 28 \\
\text { February } 2020\end{array}$ & $\begin{array}{l}\text { In teaching writing, there are number of strategies that can be } \\
\text { used. This study was intended to explore (1) the teaching writing } \\
\text { strategies used by the teacher, (2) the differences in teaching, and (3) } \\
\text { the problems encountered by the English teacher in teaching writing } \\
\text { skill. This study was a descriptive qualitative study. Teachers from } \\
\text { Bintang Mandiri and Widyatmika Junior High Schools were involved as } \\
\text { the informant of the study. They were observed during the teaching and } \\
\text { learning process and also interviewed. The data taken from observation } \\
\text { and interview were analyzed in order to find out the answer the research }\end{array}$ \\
\hline $\begin{array}{l}\text { Keywords: } \\
\text { Strategy, Teaching, } \\
\text { Writing }\end{array}$ & $\begin{array}{l}\text { more teaching writing strategy namely creative writing while in } \\
\text { Widyatmika, creative writing was not identified. There were three main } \\
\text { problems identified from the teachers. The first was students' difficulties } \\
\text { in expressing ideas in English. The second problem was students' } \\
\text { grammar. The third was students' passiveness in classroom. } \\
\text { Suggestions and implications are furtherly discussed. }\end{array}$ \\
\hline
\end{tabular}




\section{Introduction}

To be defined as a good English speaker, there are four major skills that should be mastered namely: listening, reading, writing and speaking. Among the four skills, Zemach and Islam (2005) mention that writing is one of the most difficult skills to learn especially for foreign language students. It is because students need to consider many linguistic aspects such as grammar and vocabulary. However, writing is important for students. Besides as a form of communication, writing is a necessary activity in everyday lives such in business, creativity, and in scholarly pursuits (Walsh, 2010; Kestha \& Harb, 2013). In EFL context, Rao (2007) explains that writing skill stimulates thinking, compels students to concentrate and organize their ideas, and cultivates their ability to summarize, analyze, and criticize.

Along the process of writing, Ariyanti and Fitriana (2017) found that students have major writing difficulties in grammatical, cohesion and coherence terms. Moreover, they also identified students' minor writing difficulties such as paragraph organization, dictions, and vocabulary misspelling. they also identified students' minor writing difficulties such as paragraph organization, dictions, and vocabulary misspelling. This indicated that writing is not an easy task for students especially EFL students. Therefore, the present of teacher is very essential for students during their writing process.

Teachers are required to teach writing to the students effectively. In teaching writing, the teacher's role is facilitator. As a facilitator, the teacher offers guidance in helping students to engage in the

thinking process of writing (Brown, 2000). However, the teaching writing is a very demanding task and there will be challenges for teacher. The challenges are related to: the linguistic and the cultural differences between the target language and the native language, the learners, the teachers, and the teaching context (Nasser, 2016). In facing the challenges, Reiser (2002) suggests that teachers can use different strategies of teaching to achieve the teaching-learning goals. A correct and appropriate strategy may help the students along the process of writing.

It can be said that in teaching writing, teaching strategies become a very important aspect in the teaching and learning process. Selecting the right strategy enables teacher and students to achieve the learning goals. In addition, the use of appropriate strategy can motivate students in the learning process of writing. There are many strategies that teachers can use in teaching writing. These strategies have their advantages and disadvantages. Seeing the importance of the role of teaching writing strategies, this research was conducted to explore teaching writing strategies used by teachers. In addition, this research will also explore the difficulties faced by teachers in teaching writing

\section{Methods}

The current study was designed in descriptive qualitative research specifically in a form of a case study. The subjects of the present study were English teachers in two private schools namely Bintang Mandiri and Widyatmika junior high schools. There were four English teachers in Bintang Mandiri and four English teachers in Widyatmika. The objects of the study were the English teacher strategies used and problems in teaching writing faced by the teacher in Bintang Mandiri and Widyatmika junior high schools.

In collecting the data, the researcher conducted observation, interview and documentation. The data then analyzed descriptively and also analyzed using interactive model proposed by Miles and Huberman (1994). The analysis consists of four steps namely data collection, data reduction, data display and conclusion drawing.

\section{Result And Discussion}

From several observations in Bintang Mandiri, the strategies used by 4 English teachers in teaching writing were identified. The result of observations is presented in Table 1

Table 1. Strategies in Teaching Writing in Bintang Mandiri

\begin{tabular}{|c|c|c|c|c|c|c|c|}
\hline \multirow{2}{*}{$\begin{array}{l}\text { Teaching } \\
\text { Strategy }\end{array}$} & \multicolumn{7}{|c|}{ Observation } \\
\hline & 1 & 2 & 3 & 4 & 5 & 6 & 7 \\
\hline $\begin{array}{l}\text { Mind Mapping } \\
\text { PLEASE } \\
\text { Guide Writing }\end{array}$ & $\sqrt{ }$ & $\sqrt{ }$ & $\sqrt{ }$ & $\sqrt{ }$ & $\sqrt{ }$ & & \\
\hline Creative Writing & & & & & & $\sqrt{ }$ & $\sqrt{ }$ \\
\hline Date & $4^{\text {th }}$ April & $11^{\text {th }}$ April & $18^{\text {th }}$ April & $25^{\text {th }}$ April & $2^{\text {nd }}$ May & $9^{\text {th }}$ May & $16^{\text {th }}$ May \\
\hline
\end{tabular}




$\begin{array}{lllllll}2019 & 2019 & 2019 & 2019 & 2019 & 2019 & 2019\end{array}$

By looking at Table 1, the teaching strategy used in teaching writing at Bintang Mandiri were mind mapping strategy, PLEASE strategy, guided writing strategy and creative writing strategy.

From several observations in Widyatmika school, the strategies used by English teacher in teaching writing were identified. The result of observations is presented in Table 2

Table 2 Strategies in Teaching Writing in Widyatmika

\begin{tabular}{|c|c|c|c|c|c|c|c|}
\hline Teaching & Observatic & & & & & & \\
\hline Strategy & 1 & 2 & 3 & 4 & 5 & 6 & 7 \\
\hline $\begin{array}{l}\text { Mind Mapping } \\
\text { PLEASE } \\
\text { Creative Writing } \\
\text { TAD }\end{array}$ & $\sqrt{ }$ & $\sqrt{ }$ & $\sqrt{ }$ & $\sqrt{ }$ & $\sqrt{ }$ & $\sqrt{ }$ & $\sqrt{ }$ \\
\hline Date & $\begin{array}{l}5^{\text {th }} \text { April } \\
2019\end{array}$ & $\begin{array}{l}12^{\text {th }} \text { April } \\
2019\end{array}$ & $\begin{array}{l}\text { 19th April } \\
2019\end{array}$ & $\begin{array}{l}26^{\text {th }} \text { April } \\
2019\end{array}$ & $\begin{array}{l}3^{\text {rd }} \text { May } \\
2019\end{array}$ & $\begin{array}{l}10^{\text {th }} \text { May } \\
2019\end{array}$ & $\begin{array}{l}17^{\text {th }} \text { May } \\
2019\end{array}$ \\
\hline
\end{tabular}

By looking at Table 2 the teaching strategy used in teaching writing at Widyatmika were mind mapping strategy. PLEASE strategy, guided writing strategy and TAD strategy.

It was identified that the teaching strategy used in teaching writing at Bintang Mandiri were mind mapping strategy, PLEASE strategy, guided writing strategy and creative writing strategy. Meanwhile, the teaching strategy used in teaching writing at Widyatmika were mind mapping strategy. PLEASE strategy, guided writing strategy and TAD strategy. In Bintang Mandiri the teacher used 1 more teaching writing strategy namely creative writing while in Widyatmika, creative writing was not identified.

In comparing strategies of teaching writing in Bintang Mandiri and Widyatmika, the teacher in Bintang Mandiri used more variety of teaching strategy. In Bintang Mandiri, creative writing was used by the teacher in teaching writing. Creative writing becomes an interesting strategy in learning English. It was realized that this strategy was rarely used in class because most teachers only focused on students' academic skills.

From the interview, the teachers confessed that the problems that the students faced were grammar, vocabulary, and students' passiveness in classroom. These linguistics problems are commonly found when the students have low learning motivation and also commonly experienced by students who just begun to learn English. These problems are common for EFL students especially students who just begin to learn English. Students found to have linguistics and low reading competency problems. They said that they still have low understanding on grammar and they were stuck in developing paragraph during the process of writing.

The findings of the studies imply that there are a number of strategies of teaching writing that can be adopted by teacher especially in EFL context. Besides strategies of teaching writing identified in this study, Jurianto, Salimah and Kwary (2016) state that teacher can apply collaborative writing, sentence combining, prewriting, study of models and inquiry activities. The implementation of strategies of teaching writing should be directed by the teacher by considering the learning goal and the students' competency.

During the teaching and learning process, students were struggle in developing their writing. As what found in the study, students' lack of vocabulary, grammar and motivation made them difficult to express their idea in English. This was also in line with Alfaki (2015) who found that during the writing process, students faced some linguistic difficulties such as grammatical, mechanical, sentence structure and diction problems. Rahmatunisa (2014) also found that the main problems faced by the EFL students in essay writing, specifically, linguistics, cognitive, and psychological problems. Younes and Albalawi (2015) found kind of different major problems faced by the students in three ways, namely grammatical, punctuation, and spelling problems. Thus, grammar could be said as the main problem that the students faced in developing their writing.

Even though this study is limited to number of participants, and the results cannot be generalized, the researcher believe that the strategies can be implemented to enhance help the students during their writing process. The teacher should aware that those strategies of teaching writing have their own strengths and weaknesses. Therefore, the teacher needs to choose the most relevant strategy for the students by taking into consideration on the materials, students' condition and competence. Besides that, 
teachers needed to enhance themselves in broadening knowledge and skill of teaching writing especially in 21st learning context.

\section{Conclussion}

Based on the result of the study it can be conclude that the implementation of strategies of teaching writing should be directed by the teacher by considering the learning goal and the students' competency. During the teaching and learning process, students were struggle in developing their writing. As what found in the study, students' lack of vocabulary, grammar and motivation made them difficult to express their idea in English. The most important thing is that the teacher should focus on the process of writing instead of product. This was due to the context of foreign language in which the students have limitation in practicing the target language. The other reason to focus on process of writing is because the students can be categorized as new learner of English because English is taught started from junior high school based on national curriculum of Indonesia. Teacher is suggested to read literature and develop teaching writing that is suitable for the students. Teachers are also suggested to integrate the strategy of teaching writing with technology so the students are more motivated in learning English.

\section{Reference}

Alfaki, I. (2015). University Students' English Writing Problems: Diagnosis and Remedy. International Journal of English Language Teaching, 3(3), 40-52.

Ariyanti, A. and Fitriana, R. (2017). EFL Students' Difficulties and Needs in Essay Writing. Advances in Social Science, Education and Humanities Research (ASSEHR), volume 158 International Conference on Teacher Training and Education 2017 (ICTTE 2017)

Brown, H. D. (2000). Teaching by Principles (2nd Edition ed.). San Francisco: Longman.

Jurianto, Salimah, and Kwary, A. (2015). Strategies For Teaching Writing in EFL Class at A Senior High School in Indonesia. CELT, 15(1). 1-10.

Kestha. A., S. \& Harb., I., I. (2013). The Effectiveness of Blended Learning Program on Developing Palestinian Tenth Graders' English Writing Skills. Educational Journal. 2(6), 208-221.

Miles, M and Huberman, A. (1994). Qualitative Data Analysis. London: Sage Pub.

Rahmatunisa, W. (2014). Problems Faced by Indonesian EFL Learners in Writing Argumentative Essay. English Review: Journal of English Education, 3(1), 1-9.

Rao, T. (2007) 'Training in brainstorming and developing writing skills. ELT Journal, 61(2), 100-106.

Reiser, L. J. (2002). Professional development and other factors that contribute to the ability to integrate technology into curriculum. Journal of Educational Technology Systems, 30(4), 437-460.

Walsh, K. (2010). The importance of writing skills: Online tools to encourage success. Retrieved June 27th, 2019, from http://www.emergingedtech.com/2010/11/the-|importance-of-writing-skills-onlinetools-to-encourage-success/

Younes, Z. and Albalawi, F. (2015). Exploring the Most Common Types of Writing Problems Among English Language and Translation Major Sophomore Female Students at Tabuk University. Asian Journal of Basic and Applied Sciences, 3(2), 7-26.

Zemach, E., \& Islam, C. (2005). Paragraph Writing. Macmillan: Macmillan Publisher Limited 